\title{
TRAPPING MAMMALS IN A CAUTIOUS WORLD: THE EFFECT OF DISINFECTANTS ON TRAP SUCCESS
}

\author{
J.A. Wilson ${ }^{1,3}$ and K.E. Mabry 2,4
}

\begin{abstract}
Disinfecting traps that have captured small mammals is one recommendation for preventing occurrence of hantavirus infection; however, the potential effects of disinfection on small mammal trappability have not been investigated thoroughly. We conducted an experiment to compare the effects of 2 disinfectants (Lysol ${ }^{\circledR}$ and household bleach) on the trappability of 4 small mammal species (Peromyscus maniculatus, Neotamias spp., and Spermophilus lateralis). We established triplicate trap grids in 2 forest types (red fir and mixed conifer), each consisting of a $6 \times 6$ array of Sherman live-traps placed at 10-m intervals. Traps were given 1 of 3 treatments: control (water), Lysol, or bleach; the treated traps were placed in an alternating pattern. Traps were open for 4 consecutive nights with daily treatment application. We found a difference in the trappability of Peromyscus between years; however, we did not detect a statistically significant difference in trappability resulting from disinfection for any of the 3 study species. Disinfectant effects on capture probability within Peromyscus were not supported by model selection in Program MARK. Collectively, these results indicate that although populations may fluctuate temporally and spatially, trap disinfection does not have a significant effect on small mammal trappability.
\end{abstract}

Key words: bleach, capture success, disinfectants, hantavirus, Lysol ${ }^{\circledR}$, Peromyscus.

RESUMEn.-Una de las recomendaciones para prevenir el hantavirus es la de desinfectar las trampas en las que se ha atrapado a pequeños mamíferos. Sin embargo, no se han investigado extensamente los posibles efectos de la desinfección en la facilidad de captura de los pequeños mamíferos. Llevamos a cabo un experimento para comparar los efectos de dos desinfectantes (Lysol ${ }^{\circledR}$ y cloro) en la facilidad de captura de cuatro especies de pequeños mamíferos (Peromyscus maniculatus, Neotamias spp. y Spermophilus lateralis). Hicimos una cuadrícula triplicada de trampas en dos tipos de bosque (abeto rojo y coníferas mixtas); cada cual constaba de una distribución $6 \times 6$ de trampas Sherman de captura viva separadas por $10 \mathrm{~m}$. Se lavaron las trampas con uno de tres líquidos: agua (el control), Lysol o cloro. Se colocaron de tal manera que alternaba de forma regular el uso de los tres líquidos. Operamos las trampas durante cuatro noches consecutivas, lavándolas a diario. Detectamos una diferencia en la facilidad de captura de Peromyscus de un año a otro; sin embargo, no detectamos ninguna diferencia estadísticamente significativa en la facilidad de captura que se pueda atribuir a la desinfección para ninguna de las tres especies estudiadas. Para Peromyscus, la selección de modelos en Program MARK no respalda la hipótesis de que la desinfección afecta la probabilidad de captura. Estos resultados indican que mientras que las poblaciones pueden fluctuar temporal y espacialmente, la desinfección de trampas no tiene ningún efecto significativo en la facilidad de captura de pequeños mamíferos.

During spring 1993, the first cases of Sin Nombre virus (hantavirus) were reported from the Four Corners region of the United States (Elliott et al. 1994, Mills et al. 1995a). Although the human mortality rate was first reported to be about $70 \%$, it has since declined to approximately $30 \%-40 \%$, despite the lack of a successful treatment or cure (Yates et al. 2002). Since the 1993 outbreak, the origins of hantaviruses have been discovered, and a number of additional strains have been identified throughout the world (Lee et al. 1978, Mills et al. 1995a). Rodents have been identified as the primary vector for hantaviruses (Lee et al. 1985,
LeDuc et al. 1986, Yanagihara and Gajdusek 1987, Childs et al. 1988, Mills et al. 1995a). In the United States, the deer mouse (Peromyscus maniculatus) has been identified as the primary reservoir host for hantavirus, including Sin Nombre (Childs et al. 1994); however, other rodents, including cotton rats (Sigmodon spp.), voles (Microtus spp.), and Old World rats (Rattus rattus and Rattus norvegicus), are also known vectors.

Humans become infected with Sin Nombre virus through exposure of their mucosal tissue to contaminated urine or feces (Peters and Khan 2002). The most common means of exposure

\footnotetext{
${ }^{1}$ Wildlife, Fish, and Conservation Biology, University of California, Davis, CA 95616

${ }^{2}$ Section of Evolution and Ecology, University of California, Davis, CA 95616.

${ }^{3}$ Present address: Department of Biological Sciences, University of Nebraska, Omaha, NE 68182. E-mail: jameswilson@unomaha.edu

${ }^{4}$ Present address: Department of Biological Sciences, New Mexico State University, Las Cruces, NM 88003.
} 
comes from cleaning rodent-infested areas (i.e., houses, cabins, etc.) without proper respiratory protection; though, there have been some reports of transmission through a bite by an infected rodent (Dournon et al. 1984). Humanto-human transmission of the virus occurs rarely, if ever (Wells et al. 1997).

In 1995, the American Society of Mammalogists published protective guidelines for field mammalogists. The guidelines state that rodents should be handled outdoors and downwind of the researcher whenever possible (Mills et al. 1995b). Persons handling potentially infected rodents should wear appropriate personal protective gear: most notably, latex gloves and a respirator (Mills et al. 1995a). In addition, all traps that come in contact with rodents should be disinfected with hospital-grade disinfectant (10\% bleach or Lysol $\left.^{\circledR}\right)$.

These guidelines were adopted to protect researchers from being infected; however, the use of disinfectants may alter rodent behaviors in ways critical to research. Specifically, residual odors of disinfectants could affect a rodent's trappability and lead to biased population estimates. Few studies have focused on how trap odor affects trap success, with most focusing on lingering rodent odors (Mazdzer et al. 1976, Drickamer 1984, Heske 1987, Gurnell and Little 1992) and only 2 on disinfectant use (Yunger and Randa 1999, Van Horn and Douglass 2000). Odors from conspecifics of the opposite sex increased the likelihood of trapping white-footed mice (Peromyscus leucopus; Mazdzer et al. 1976). Similarly, Gurnell and Little (1992) found that more animals entered dirty traps than clean traps, and these animals were particularly attracted to traps with conspecific odors. Though natural odor seems to play an important role in trap success, neither Yunger and Randa (1999) nor Van Horn and Douglass (2000) found an effect of disinfection on trap success.

The 2 previous studies examined the effect of a single disinfectant rather than simultaneously comparing multiple disinfectants. Yunger and Randa (1999) tested traps treated with bleach or water for differences in trap success; Van Horn and Douglass (2000) used Lysol as a disinfectant treatment but did not use a standard no-treatment control. Instead they tested for differences in trap success between disinfected traps that varied in time since disinfection ( $\leq 8$ hours versus $\geq 5$ days).
This study was designed to investigate the potential effect of disinfection on trap success. We compared the 2 most common disinfectants used by researchers (bleach and Lysol) to a control treatment (water). We performed the experiment in 2 habitats: a red fir forest with high rodent abundance and a mixed conifer forest with low rodent abundance. Though there is evidence that disinfection does not reduce trap success, we predicted that use of disinfectants would decrease trap success compared to control traps. Conspecific odor has been shown to be an attractant (Mazdzer et al. 1976, Drickamer 1984, Heske 1987, Gurnell and Little 1992), and the use of disinfectant should eliminate these odors, leading to lower trap success. We also predicted a difference in trap success between bleach and Lysol, although we had no $a$ priori reason to predict which treatment might have higher trap success.

\section{Methods}

We conducted this study in 2 study areas in the Plumas National Forest surrounding Quincy, California. One area was in a red fir forest and the other was in a mixed conifer forest. Red fir (Abies magnifica) dominated the red fir forest, and western white pine (Pinus monticola) and lodgepole pine (Pinus contorta) were distributed throughout the area. The understory was composed of a thick layer of prostrate manzanita (Arctostaphylos palustrus) with numerous fallen logs, coarse woody debris, and large granite rocks and boulders. Mixed conifer sites were composed of ponderosa pine (Pinus ponderosa), sugar pine (Pinus lambertiana), Douglas-fir (Pseudostuga menziesii), and white fir (Abies concolor). Results from a California Department of Health investigation showed that the study areas were known to contain deer mice (Peromyscus maniculatus), approximately $50 \%$ of which were seropositive for hantavirus. All work was performed under an approved Institutional Animal Care and Use Committee (IACUC) protocol and followed guidelines of the American Society of Mammalogists.

We established a set of triplicate trap grids in each of the 2 forest types; each grid consisted of a $6 \times 6$ array of XLK Sherman live-traps (H.B. Sherman, Tallahassee, FL) with 10-m spacing. A single trap was placed at the intersection points of the grid, for a total of 36 traps per grid. Traps were given 1 of 3 
TABLE 1. Results of Program MARK analysis for disinfection effects. Apparent survival was held constant (.) while capture probability $(\mathrm{p})$ and probability of movement between disinfection types (phi) were changed. Models included habtiat (red fir, mixed conifer), time (month), or disinfection (Lysol ${ }^{\circledR}$, bleach). Best-fit models are shown for each species. Akaike's corrected information coefficient $\left(\mathrm{AIC}_{c}\right)$, adjusted for overdispersion, and the model weight relative to other less-fit models are given.

\begin{tabular}{lll}
\hline Model & $\mathrm{AIC}_{c}$ & Weight \\
\hline$\Phi(.) \mathrm{p}($ habitat*t)phi(.) & 278.9 & 0.53 \\
$\Phi(.) \mathrm{p}(\mathrm{t})$ phi(.) & 280.7 & 0.21 \\
$\Phi(.) \mathrm{p}($ habitat*t)phi(dis) & 281.8 & 0.12 \\
\hline
\end{tabular}

treatments-control, Lysol, or bleach-and were placed so the 3 treatments alternated in a regular pattern. All traps were soaked for approximately 30 minutes in their respective treatment solution, rinsed twice in water, and allowed to air dry. Control traps were soaked in tap water. Bleach traps were soaked in a $10 \%$ Clorox ${ }^{\circledR}$ Regular-Bleach solution (active ingredients in the undiluted product: $5 \%-10 \%$ sodium hypochlorite and $<1 \%$ sodium hydroxide). Lysol traps were soaked in a 5\% Lysol Concentrate Disinfectant solution (original scent; active ingredient: benzalkonium chloride)

Traps were placed on the grid during the morning of the first day and were sprayed with 2 pumps (approximately $2.5 \mathrm{~mL}$ ) from a spray bottle containing the respective treatment solution. Following spraying, traps were closed and allowed to air dry in place. In the evening, traps were baited with rolled oats and black oil sunflower seeds coated in peanut butter and opened for the night. All traps were checked the following morning, and every trap was sprayed with 2 pumps of treatment solution, regardless of whether it caught an animal or not. If a trap caught an animal, the species was noted, the animal was given a uniquely numbered Monel eartag (National Band and Tag, Newport, KY), and standard information was recorded (i.e., capture location, trap treatment, sex, reproductive condition, mass, and age). Animals were released at the site of capture. All traps were closed following spraying, allowed to air dry, and reopened that evening. Traps were opened for 3 (August 2004) or 4 (May and September 2005) consecutive nights.

Estimates of capture probability (p) and the probability of movement $(\mathrm{Y})$ between disinfection types were made using the multistrata data type in Program MARK (White and Burnham 1999). The factors used to build a priori models of capture probability and movement were no difference (.), disinfection type (control, Lysol, bleach), and treatment (disinfected or control). Treatment models represented the effect of any disinfectant (presumably an unnatural scent), whereas disinfection type tested the effects of individual disinfectants. Capture data was tested for goodness of fit using Program MARK and adjusted $\hat{c}$ values $(\hat{c}=1.10)$. Model selection was determined by Akaike's information criterion (AIC) with models weighted with the top model.

We analyzed the data using logistic regression models with treatment (control, Lysol, bleach) as the main factor of interest and the proportion of traps on each grid that captured an individual of each species as the dependent variable. However, because of suspected differences in the number of individuals of each species captured between habitats, years, and occasions, we performed logistic regressions within a number of stratified analyses. In the red fir habitat, we performed a full-model logistic regression for each species that included treatment, year (2004, or 2005), occasion (trap day), and a 3-way interaction term. Mixed conifer sites were only trapped in 2005 , so we could not perform a full model on 2004 analyses. In addition, for each habitat (red fir and mixed conifer) and species, we performed a logistic regression by year with treatment, occasion, and their interaction as the terms. We used PROC LOGISTIC in SAS (SAS Institute, Inc. 2002) to perform the analyses. Our a priori criterion for significance was $P \leq 0.05$. All means are presented with standard errors.

\section{RESULTS}

Program MARK identified 3 models with support (Table 1). The model with the greatest support was the null model (no effect of disinfection), which had more than twice the support of the next highest model, a model containing only disinfectant effects on capture probability. Probability of capture within the null model was $0.80(\mathrm{SE}=0.08)$ for any trap, independent of disinfection treatment. The last model with support included only disinfectant effects on movement probability. Effects of disinfectant type on capture probability (as indicated by model 2) showed a reduction in capture probability from disinfection $(0.76, \mathrm{SE}=0.11)$ compared to control traps $(0.87, \mathrm{SE}=0.15)$. 

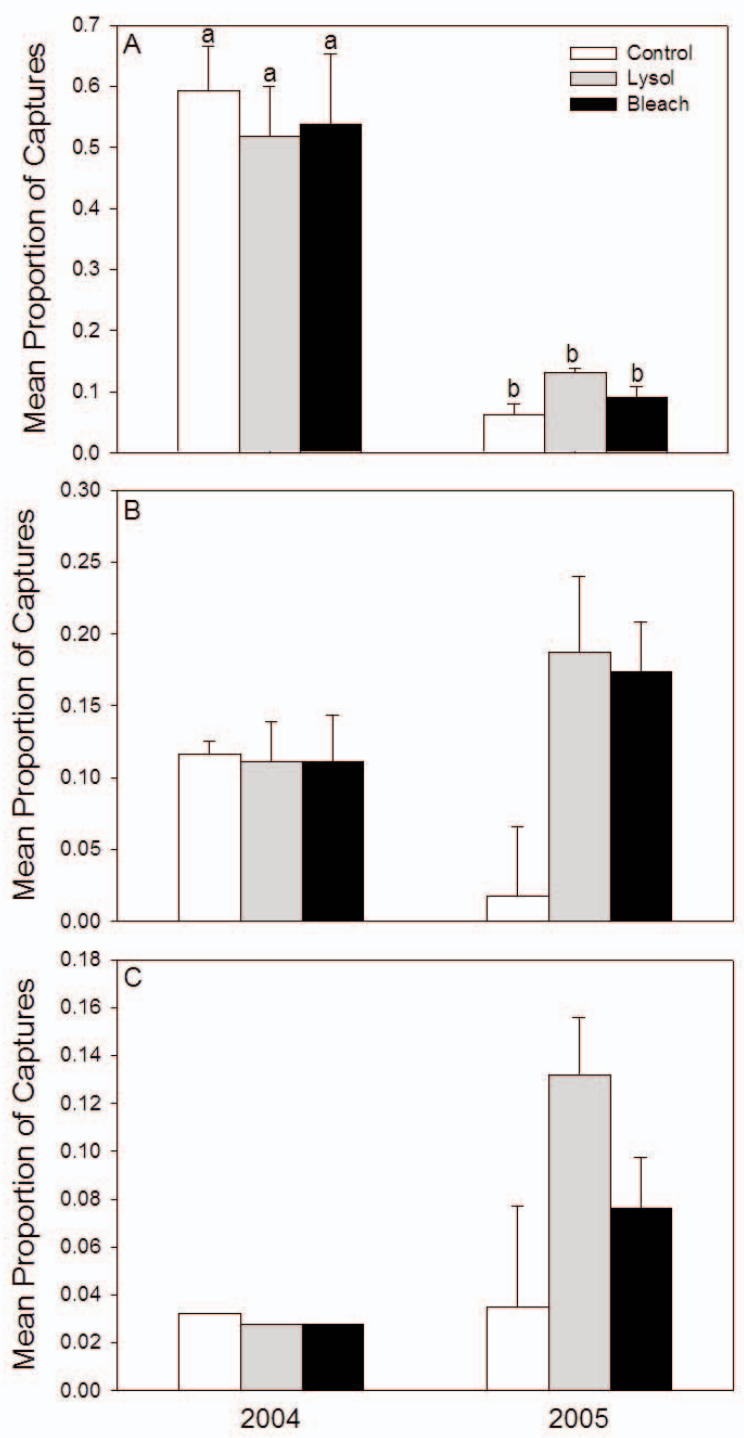

Fig. 1. Mean proportion of captures within red fir forests of (A) deer mice (Peromyscus maniculatus), (B) chipmunks (Neotamias sp.), and (C) golden-mantled ground squirrels (Spermophilus lateralis) in traps treated with Lysol ${ }^{\circledR}$, bleach, or water (control).

Similarly, movement was affected somewhat by which trap an individual visited first. Individuals visiting a control trap first were less likely to move to a disinfected trap $(\mathrm{Y}=0.23$, $\mathrm{SE}=0.05)$ compared to individuals moving from a disinfected trap to a control trap $(\mathrm{Y}=$ $0.28, \mathrm{SE}=0.07)$. Probability of movement between disinfected traps (Lysol to bleach, or bleach to Lysol) was greatest $(0.32, \mathrm{SE}=0.07)$.

Trap success differed temporally and spatially with the red fir forest grids having much greater success $(72 \%, 2004 ; 38 \%, 2005)$ than grids in mixed conifer sites $(9 \%, 2005)$. We trapped in red fir forest sites during both years; a yearly difference was observed in the population of all rodent species, but the difference was especially large for Peromyscus maniculatus (Fig. 1). In red fir forests, $P$. maniculatus was more abundant in 2004 (102 individuals) than in 2005 (16 individuals). We captured 26 individuals of Peromyscus in the mixed conifer forest during 2005 trapping. In contrast, fewer Spermophilus 
TABLE 2. Results of logistic regression by year for 3 species of rodents captured in red fir or mixed conifer forests in the northern Sierra Nevada. Species captured are Peromyscus maniculatus (PEMA), Neotamias sp. (NESP), and Spermophilus lateralis (SPLA). Mixed conifer sites were only trapped in 2005 and contained no SPLA. Treament (control, Lysol ${ }^{\circledR}$, bleach) and day of trapping (occasion) were used for model factors (effect).

\begin{tabular}{|c|c|c|c|c|c|c|}
\hline Habitat & Species & Year & Effect & $\mathrm{df}$ & $\chi^{2}$ & $P$ \\
\hline \multirow[t]{15}{*}{ Red fir } & \multirow[t]{6}{*}{ PEMA } & \multirow[t]{3}{*}{2004} & Treatment & 2 & 1.35 & 0.508 \\
\hline & & & Occasion & 2 & 19.04 & $<0.0001$ \\
\hline & & & Interaction & 4 & 2.47 & 0.650 \\
\hline & & \multirow[t]{3}{*}{2005} & Treatment & 2 & 4.49 & 0.106 \\
\hline & & & Occasion & 3 & 1.29 & 0.733 \\
\hline & & & Interaction & 6 & 2.96 & 0.813 \\
\hline & \multirow[t]{6}{*}{ NESP } & \multirow[t]{3}{*}{2004} & Treatment & 2 & 1.33 & 0.515 \\
\hline & & & Occasion & 2 & 1.42 & 0.492 \\
\hline & & & Interaction & 4 & 2.89 & 0.576 \\
\hline & & \multirow[t]{3}{*}{2005} & Treatment & 2 & 0.47 & 0.790 \\
\hline & & & Occasion & 3 & 13.29 & 0.004 \\
\hline & & & Interaction & 6 & 6.49 & 0.370 \\
\hline & \multirow[t]{3}{*}{ SPLA } & \multirow[t]{3}{*}{2005} & Treatment & 2 & 2.51 & 0.285 \\
\hline & & & Occasion & 3 & 2.55 & 0.467 \\
\hline & & & Interaction & 6 & 4.53 & 0.476 \\
\hline \multirow[t]{3}{*}{ Mixed conifer } & \multirow[t]{3}{*}{ PEMA } & \multirow[t]{3}{*}{2005} & Treatment & 2 & 1.42 & 0.491 \\
\hline & & & Occasion & 4 & 6.07 & 0.194 \\
\hline & & & Interaction & 7 & 2.89 & 0.895 \\
\hline
\end{tabular}

lateralis individuals were captured in 2004 (2 individuals) than in 2005 (28 individuals). Captures of Neotamias remained relatively constant across both years. We trapped in mixed conifer sites only in 2005, and our trapping there represented an attempt to sample a low density area. Capture rates were lowest in the mixed conifer sites, with 26 and 3 unique individuals of Peromyscus and Neotamias captured. In addition to the above species, we also captured montane voles (Microtus montanus), long-tailed voles (Microtus longicaudus), shrews (Sorex spp.), and one long-tailed weasel (Mustela frenata).

A full model with treatment, year, occasion, and a 3-way interaction term was utilized to identify what factors, if any, were important to each rodent species. Because mixed conifer sites were not trapped in 2004, they were not included in the full-model logistic regression. In the red fir forest, a yearly difference in the proportion of captures of $P$. maniculatus was observed $\left(\chi^{2}=125.6\right.$, df $\left.=1, P<0.001\right)$, with capture numbers in 2004 being substantially greater than in 2005 (Fig. 1a). Although an annual difference was detected for Peromyscus, no effect of trap treatment was observed for any of the 3 species $(P$. maniculatus: $\chi^{2}=1.87, \mathrm{df}=2, P=0.4 ;$ Neotamias spp.: $\chi^{2}=0.03, \mathrm{df}=2, P=0.9 ;$ S. lateralis: $\chi^{2}$ $=2.44, \mathrm{df}=2, P=0.3$; Fig. 1 ). No significant interactions were detected for any of the species (P. maniculatus: $\chi^{2}=5.29, \mathrm{df}=6, P=0.5$; Neotamias spp.: $\chi^{2}=5.95, \mathrm{df}=6, P=0.4 ; S$. lateralis: $\left.\chi^{2}=4.68, \mathrm{df}=6, P=0.6\right)$.

To investigate variation within each site, logistic regressions were run independently for each species, year, and habitat to determine if treatment affected trap success on any of the grids sampled (Table 2). Within mixed conifer sites, $P$. maniculatus was the only species with enough captures to perform an analysis. We did not observe a treatment effect for any of the species or within either habitat type (Table 2). The only significant differences observed were in red fir sites and occurred between individual trap days (occasion) for Peromyscus in 2004 ( $\chi^{2}$ $=19.04, \mathrm{df}=2, P<0.0001)$ and Neotamias in $2005\left(\chi^{2}=13.29\right.$, df $=2, P=0.6$; Table 2$)$.

\section{Discussion}

During 2004, we trapped the red fir forest site with high trap success $(72 \%)$ on all grids. Because we only checked traps in the morning, we were unable to determine in what pattern rodents occupied the traps (i.e., were control traps used first, then disinfected traps, or were traps used randomly). We felt that the high proportion of captures might wash out any patterns of capture that occurred in response 
to the disinfectant treatment. Therefore, we repeated the experiment the following year and added a low density site-the mixed conifer forest. Rodent abundance was lower the second year in red fir sites; mixed conifer sites had an even lower abundance. Results from both years and habitats showed no effect when traps were disinfected with either Lysol or bleach. These results are consistent over a wide range of population densities. Our results agree with previous studies that tested the effects of residual disinfectant odors on trap success (Yunger and Randa 1999, Van Horn and Douglass 2000). Our results provide further evidence that even daily disinfection of traps does not affect the trappability of rodents, suggesting that safety and data collection are not necessarily antagonistic.

Results from Program MARK showed the model with no disinfectant effects to have more than twice as much support as those including disinfectant effects. In our opinion, this result shows that trap disinfection with bleach or Lysol, has no effect on live-trapping efforts. However, there was some support for a minimal reduction in trap success due to disinfectants. Results from the MARK analysis showed that the use of disinfectants on traps lowered capture probability by $7.5 \%$. However, this effect is only be observed when rodents have a choice between both disinfected and control traps. During normal, hantavirus-safe trapping, only disinfected traps would be available to rodents. Therefore, we feel that such a small reduction in capture success would be functionally insignificant. In addition, our results show that once an individual visits a disinfected trap, it is more likely to visit another disinfected trap over a control trap. This result indicates that, upon visiting a disinfected trap, individuals may lose any sensitivity they may have had to anthropogenic smells.

The guidelines and suggestions provided by Mills et al. (1995b) are sufficient to protect scientists that perform live-trapping field studies involving potentially infected rodents; however, these guidelines may be overly cautious and restrict potential data collection or studies because of the dangers associated with wearing protective gear, especially at high altitudes and during excessively hot weather. A consensus of what constitutes appropriate safety equipment and procedures needs to be determined so field mammalogists can perform valid studies while still protecting their health. Regardless of what safety measures become the standard for field mammalogists, disinfection will surely be among the procedures used in any study of rodents. Our study provides further evidence that trap disinfection can be used without biasing live-capture data.

\section{ACKNOWLEDGMENTS}

This study was funded in part by a grant from the U.S. Forest Service to D.A. Kelt, D.H. Van Vuren, and M.B. Johnson. We thank D.A. Kelt for the use of equipment and editing, D.H. Van Vuren for editing, and Jerome Braun for statistical help. K.E. Mabry was supported by an EPA STAR Fellowship during this study.

\section{Literature Cited}

Childs, J.E., G.E. Glass, G.W. Korch, and J.W. DeLuc. 1988. The ecology and epizootiology of hantaviral infections in small mammal communities of Baltimore: a review and synthesis. Bulletin of the Society of Vector Ecology 13:113-122.

Childs, J.E., T.G. KsiazeK, C.F. Spiropoulou, J.W. Krebs, S. Morzunov, G.O. Maupin, K.L. Gage, P.E. Rollin, J. SARISKY, R.E. ENSCORE, ET AL. 1994. Serologic and genetic identification of Peromyscus maniculatus as the primary rodent reservoir for a new hantavirus in the southwestern United States. Journal of Infectious Diseases 169:1271-1280.

Dournon, E., B. Moriniere, B. Matheron, P.M. Girard, J.P. GonZalez, F. HiRsCH, AND J.S. MCCORMICK. 1984 Hemorrhagic fever with renal syndrome after a wild rodent bite in Haute-Savoie and risk of exposure to Hantaan-like virus in a Paris laboratory. Lancet 1984:676-677.

Drickamer, L.C. 1984. Captures of two species of Peromyscus at live traps baited with male and female odors. Journal of Mammalogy 65:699-702.

Elliot, L.H., T.G. KsiazeK, P.E. Rollin, C.F. Spiropoulou, S. Morzunov, M. Monroe, C.S. Goldsmith, C.D. Humphrey, S.R. ZaKi, J.W. Krebs, et AL. 1994. Isolation of the causative agent of hantavirus pulmonary syndrome. American Journal of Tropical Medicine and Hygiene 51:102-108.

Gurnell, J., AND J. LitTle. 1992. The influence of trap residual odor on catching woodland rodents. Animal Behaviour 43:623-632.

Heske, E.J. 1987. Responses of a population of California voles, Microtus californicus, to odor-baited traps. Journal of Mammalogy 68:64-72.

LeDuc, J.W., G.A. Smith, J.E. Childs, F.P. Pinheiro, J.I. Maiztegui, B. Niklasson, A. Antoniades, D.M. Robinson, M. Khin, K.F. Shortridge, et AL. 1986. Global survey of antibody to Hantaan-related viruses among peridomestic rodents. Bulletin of the World Health Organization 64:139-144.

LEE, H.W., P.W. LEE, AND K.M. Johnson. 1978. Isolation of the etiologic agent of Korean hemorrhagic fever. Journal of Infectious Diseases 137:298-308.

Lee, P.W., H.L. Amyx, R. Yanagihara, D.C. Gajdusek, D. Goldgaber, and C.J. GibBs. 1985. Partial characterization of Prospect Hill virus isolated from meadow 
voles in the United States. Journal of Infectious Diseases 152:826-829.

Mazdzer, E., M.R. Capone, and L.C. Drickamer. 1976. Conspecific odors and trappability of deer mice (Peromyscus leucopus novemboracensis). Journal of Mammalogy 57:607-609.

Mills, J.N., J.E. Childs, T.G. Ksiazek, and C.J. Peters. 1995a. Methods for trapping and sampling small mammals for virologic testing. U.S. Department of Health and Human Services. 61 pp.

Mills, J.N., T.L. Yates, J.E. Childs, R.P. Parmenter, T.G. Ksiazek, P.E. Roluin, and C.J. Peters. 1995b. Guidelines for working with rodents potentially infected with hantavirus. Journal of Mammalogy 76: $716-722$.

Peters, C.J., And A.S. Khan. 2002. Hantavirus pulmonary syndrome: the new American hemorrhagic fever. Emerging Infections 34:1224-1231.

SAS InstituTe, Inc. 2002. Statistical Analysis System (SAS) user's guide: statistics. Version 6. SAS Institute, Inc., Cary, NC. 1686 pp.

Van Horn, R.C., AND R.J. Douglass. 2000. Disinfectant effects on capture rates of deer mice (Peromyscus maniculatus). American Midland Naturalist 143:257-260.

Wells, R.M., J. Young, R.J. Williams, L.R. Armstrong, K. Busico, A.S. Khan, T.G. KsiazeK, P.E. Roldin, S.R.
ZaKi, T. Nichol, AND C.J. Peters. 1997. Hantavirus transmission in the United States. Emerging Infectious Diseases 3:361-365.

White, G.C., And K.P. Burnham. 1999. Program MARK: survival estimation from populations of marked animals. Bird Study 46 (Supplement):120-138.

Yanagihara, R., AND D.C. Gajdusek. 1987. Hemorrhagic fever with renal syndrome: global epidemiology and ecology of hantavirus infections. Pages 171-214 in L.M. de la Maza and E.M. Peterson, editors, Medical virology VI. Elsevier, New York, NY.

Yates, T.L., J.N. Mills, C.A. Parmenter, T.G. Ksiazek, R.R. Parmenter, J.R. Vande Castle, C.H. Calisher, S.T. Nichol, K.D. АввоTT, J.C. Young, ET AL. 2002. The ecology and evolutionary history of an emergent disease: hantavirus pulmonary syndrome. BioScience 52:989-998.

YungeR, J.A., AND L.A. RANDA. 1999. Trap decontamination using hypochlorite: effects on trappability of small mammals. Journal of Mammalogy 80:1336-1340.

Received 20 November 2009 Accepted 2 August 2010 